\title{
Breast Cancer: A Review of Mammography and Clinical Breast Examination for Early Detection of Cancer
}

\author{
Gadafi Iddrisu Balali1,2*, Denis Dekugmen Yar', Vera Gobe Afua Dela1, \\ Emmanuel Effah-Yeboah ${ }^{2,3}$, Philip Asumang1, Justice Delali Akoto ${ }^{4}$, \\ Fuseini Abdallah ${ }^{5}$
}

\footnotetext{
${ }^{1}$ Department of Theoretical and Applied Biology, Kwame Nkrumah University of Science and Technology, Kumasi, Ghana

${ }^{2}$ Department of Science Education, University of Education, Winneba, Ghana

${ }^{3}$ University of Cape Coast, Cape Coast, Ghana

${ }^{4}$ School of Metallurgy and Environment, Central South University, Changsha, China

${ }^{5}$ Department of Materials Engineering, Kwame Nkrumah University of Science and Technology, Kumasi, Ghana

Email: ‘balaligadafi@gmail.com
}

How to cite this paper: Balali, G.I., Yar, D.D., Dela, V.G.A., Effah-Yeboah, E., Asumang, P., Akoto, J.D. and Abdallah, F. (2020) Breast Cancer: A Review of Mammography and Clinical Breast Examination for Early Detection of Cancer. Open Access Library Journal, 7: e6866.

https://doi.org/10.4236/oalib.1106866

Received: September 27, 2020

Accepted: October 20, 2020

Published: October 23, 2020

Copyright $\odot 2020$ by author(s) and Open Access Library Inc.

This work is licensed under the Creative Commons Attribution International License (CC BY 4.0).

http://creativecommons.org/licenses/by/4.0/

\section{(c) (i) Open Access}

\begin{abstract}
Worldwide, breast cancer is one of the most common causes of death among women. Undoubtedly, early detection of breast cancer is one of the best ways to manage and treat the disease. According to literature, Mammography and Clinical breast exams are known to be some of the best methods in early detection of breast cancer. Hence information on these two detection methods is very important for planning health policies. This study therefore aimed at reviewing the literature on breast cancer as well as examining the literature on two breast cancer detection methods and their effectiveness. Statistics show that early detection is a primary necessity in the treatment of breast cancer among women. It was also found out that mammography as being the most recommended form of detection, is mostly not available at remote areas in developing countries leading to the increased risk of deaths and hence the greater mortality in these areas. Inexperience and luck of professional know-how have been found to also contribute to the upsurge of cases at developing regions. The review recommends that stakeholders and governmental bodies should help equip such areas with mammography equipment, professional knowledge on its usage. The study also, recommends that further studies be conducted to find out the relationship between various screening methods and age groups to clarify the issue of false positives and false negatives. Also, studies should be conducted on the knowledge and usage of mammographic screening in rural areas of developing centuries.
\end{abstract}




\section{Subject Areas}

Oncology

\section{Keywords}

Breast Cancer, Risk, Cancer Screening, Mammography, CBE, Detection and Treatment

\section{Introduction}

Women's health is a sine qua non for successful reproduction in the human race whilst breast cancer is a threat to their survival across the globe [1]. It is estimated that about 508,000 women die annually from breast cancer [2]. However, in 2018, breast cancer deaths stood at 627,000 representing nearly $15 \%$ of all recorded cancer deaths among women worldwide [3]. This is an indication of an upsurge of breast cancer deaths (approximately 119,000) from 2017. There are reported high risks of breast cancer in developed countries although these risks have now become common throughout the world.

Although recorded cases of breast cancer show that developed countries suffer more from the disease, in $201150 \%$ of breast cancer death cases were from $58 \%$ of developing countries. In the United States, for instance, approximately 230,480 females were diagnosed with breast cancer and resultant death cases in the same year (2011) were around 39,520 [4]. This is a great detriment to the health of women across the globe hence the need for investigations to combat the situation. It is often said that early detection of breast cancer aids tremendously in its treatment [5] [6]. Consequently, the aftermath of the treatment of breast cancer depends on timing detection [7].

The higher variation of breast cancer survival between developed and developing countries even worsens the situation. Studies show that about $80 \%$ survival rate is high in North America, Japan, and Sweden; however, the survival rate in low income and developing countries is about 40\% [8] [9]. This phenomenon is a result of the lack of good health promotion leading to a lack of awareness, early detection programs, scarcity of adequate diagnosis and inadequate treatment facilities [10]. This has increased the numbers of women reaching late-stage of the disease leading to higher complications. Therefore there is the need for frequent updates on studies that focus on breast cancer awareness and screening methods, specifically mammography and clinical breast examination.

\section{Review of Literature}

This study employed Boolean Operators to search for published relevant literature on mammography, mammogram and clinical breast exam, breast cancer, clinical screening, diagnosis of breast cancer, and other information that have born with the topic. Academic search sites used for the study included PubMed, 
Scholar Google, and Web of Science and other sites includes WHO, International Agency for Research on Cancer, $\mathrm{CDC}$ and institutional repositories. The search style and terms such as "AND", "OR" and "NOT" "breast cancer", "women AND cancer NOT cervical" "mammogram", "clinical breast exam" "mammogram AND clinical breast exam" "mammogram OR clinical breast exam" were used respectively.

Inclusion criteria are that studies conducted on efficiency and effectiveness of Mammography and clinical breast examination were included. Exclusion criteria involve studies that are conducted on merely other forms of breast cancers examination, screening, population etc.

\subsection{Literature Search Results}

Following the specific methodology designed for this current study, the paper discovered two papers on clinical practice guidelines and two review papers on mammography and clinical breast screening. The paper also identified and included 43 studies based on the inclusion and purpose of the study. Below is a summary of the literature search results in Table 1.

\subsection{Global Distributions of Breast Cancer}

GLOBOCAN estimates that the incidence rates of breast cancer in women are 43.1 per 100,000 [18]. As of 2018, two million new cases have been reported by the global cancer observatory. A trend observed was that the highest reported cases of breast cancer were concentrated in developed countries with most of the countries in Europe. In contrast, the lowest recorded cases were found in developing countries in Africa and parts of Asia. The highest recorded incidence rate was found in Belgium (113.2) while the lowest incidence was recorded in Bhutan (5.0). Apart from Belgium, the countries with the highest rates include Luxembourg (109.3), the Netherlands (105.9), France (99.1), New Caledonia (98.0) and Lebanon (97.6). Based on WHO regions, the WHO Europe region (69.5) has the highest incident rate followed by the WHO Americas region (66.5) while the lowest incidence rates are recorded in WHO south-east Asia region (27.5). Based on continents, the Oceania continent recorded the highest incidence of $86.7 \%$ whiles the lowest was recorded in Asia (34.4\%) [19]. The graphs below indicate the distributions of the recorded incidence rates (Figure 1, Figure 2 and Figure 3).

\subsection{Global Mortality Rates}

According to WHO, in 2018, it was estimated that globally about 627,000 women died from breast cancer. An observable trend was that most of the deaths were recorded in developing countries as compared to developed, although this trend is subject to change due to increasing rates in almost every region every year. The global cancer observatory recorded that the country with the highest mortality rate per 100,000 as in 2018 was Fiji (36.9), followed by Barbados (33.1), 
Table 1. Literature search results.

\begin{tabular}{|c|c|c|c|c|c|c|}
\hline $\begin{array}{c}\text { Authors/ } \\
\text { Cancer } \\
\text { Organization }\end{array}$ & Objective & Type of screening & $\begin{array}{l}\text { Type of } \\
\text { studies }\end{array}$ & $\begin{array}{l}\text { Age } \\
\text { group }\end{array}$ & Findings & Database \\
\hline$[11]$ & $\begin{array}{l}\text { Recommendation statement on } \\
\text { screening for breast cancer in the } \\
\text { general population. }\end{array}$ & Mammography & Review & $40-49$ & $\begin{array}{l}\text { The decision to start biennial } \\
\text { screening mammography should } \\
\text { be left to the individual } \\
\text { before age } 50\end{array}$ & PubMed \\
\hline$[12]$ & $\begin{array}{l}\text { Review of the evidence } \\
\text { of } 2003 \text {, ASC. }\end{array}$ & Mammography & Review & All ages & $\begin{array}{c}\text { Mammography is good yet } \\
\text { faced with some false-positives } \\
\text { at early ages }\end{array}$ & $\begin{array}{l}\text { Scholar } \\
\text { Google } \\
\text { website }\end{array}$ \\
\hline [13] & $\begin{array}{l}\text { To detect breast cancer rate, } \\
\text { nodal status, tumour size, and } \\
\text { associated risk factors using } \\
\text { clinical breast examination (CBE) } \\
\text { and mammography as screening } \\
\text { tools in women aged } 40 \text { - } 49 \text { years. }\end{array}$ & $\begin{array}{l}\text { Clinical Best } \\
\text { Examination and } \\
\text { Mammography }\end{array}$ & $\begin{array}{l}\text { Research } \\
\text { article }\end{array}$ & $\begin{array}{l}40-49 \\
\text { years }\end{array}$ & $\begin{array}{l}\text { CBE normalized at } 90 \% \text { and } \\
\text { Mammography BI-RADS I } \\
(58.4 \%) \text { and BI-RADS II ( } 34.6 \%) \\
\text { and only } 7 \% \text { for BI-RADS II and } \\
\text { none for BI-RADS IV group }\end{array}$ & PMS \\
\hline [14] & $\begin{array}{c}\text { Differentiating imaging } \\
\text { modalities used for screening } \\
\text { women at high-risk for breast } \\
\text { cancer over the age of } 50 .\end{array}$ & $\begin{array}{l}\text { Mammography and } \\
\text { magnetic resonance } \\
\text { imaging (MRI) }\end{array}$ & $\begin{array}{l}\text { Research } \\
\text { article }\end{array}$ & 50 & $\begin{array}{l}\text { Mammography is the only } \\
\text { imaging modality proven } \\
\text { to reduce mortality from breast } \\
\text { cancer, MRI can often identify } \\
\text { smaller malignancies at a greater } \\
\text { resolution at an earlier stage. }\end{array}$ & $\begin{array}{l}\text { Scholar } \\
\text { Google }\end{array}$ \\
\hline [13] & $\begin{array}{l}\text { To detect breast cancer rate, } \\
\text { nodal status, tumour size, and } \\
\text { associated risk factors using } \\
\text { (CBE) and mammography as } \\
\text { screening tools in women } \\
\text { aged } 40 \text { - } 49 \text { years. }\end{array}$ & $\begin{array}{l}\text { Mammography } \\
\text { and CBE }\end{array}$ & $\begin{array}{l}\text { Research } \\
\text { article }\end{array}$ & $\begin{array}{l}40-49 \\
\text { years }\end{array}$ & $\begin{array}{l}\text { CBE normalized at } 90 \% \text { and } \\
\text { Mammography BI-RADS I } \\
(58.4 \%) \text { and BI-RADS II ( } 34.6 \%) \\
\text { and only } 7 \% \text { for BI-RADS II } \\
\text { and none for BI-RADS IV }\end{array}$ & $\begin{array}{l}\text { Scholar } \\
\text { Google }\end{array}$ \\
\hline [15] & $\begin{array}{l}\text { Analysis of new screening } \\
\text { methods. }\end{array}$ & Mammography & Review & $40-74$ & $\begin{array}{l}\text { Breast cancer mortality is } \\
\text { reduced by } 40 \% \text { with false } \\
\text { negatives }(15 \%-20 \% \text { and } \\
\text { positives }(10 \%) \text { of screened } \\
\text { women, } 80 \% \text { of which are resolved } \\
\text { with additional imaging, and } \\
10 \% \text {, with a breast biopsy }\end{array}$ & $\begin{array}{l}\text { Scholar } \\
\text { Google }\end{array}$ \\
\hline [16] & $\begin{array}{l}\text { Latest guidelines for } \\
\text { mammography and } \\
\text { technologic advances. }\end{array}$ & Mammography & $\begin{array}{l}\text { Guidelines } \\
\text { data }\end{array}$ & $\begin{array}{l}\text { Ages } 40 \\
\text { to } 44,45 \\
\text { to } 54 \text {, and } \\
55 \text { and } \\
\text { older }\end{array}$ & $\begin{array}{l}40 \text { - } 44 \text { should have the choice } \\
\text { of mammography stating, } 45 \text { - } 54 \\
\text { should do mammography every } \\
\text { year and } 55 \text { and above should do } \\
\text { mammograms every } 2 \text { years and } \\
\text { finally, all women should } \\
\text { continue, as long as they are } \\
\text { expected to live } 10 \text { years or more }\end{array}$ & \\
\hline [17] & $\begin{array}{l}\text { Update of the } 2002 \text { U.S. } \\
\text { Preventive Services Task Force } \\
\text { (USPSTF) recommendation } \\
\text { statement on screening for breast } \\
\text { cancer in the general population. }\end{array}$ & $\begin{array}{l}\text { Film mammography, } \\
\text { clinical breast examination, } \\
\text { breast self-examination, } \\
\text { digital mammography, } \\
\text { and magnetic resonance } \\
\text { imaging }\end{array}$ & $\begin{array}{l}\text { Clinical } \\
\text { practice } \\
\text { guidelines }\end{array}$ & $\begin{array}{c}\text { General } \\
\text { population }\end{array}$ & & \\
\hline
\end{tabular}


Somalia (29.1), Syrian Arab Republic (26.9) while the lowest mortality rate was recorded in Mongolia (4.0) and the Republic of Gambia (4.0) respectively. Based on the WHO regions, the WHO East Mediterranean region recorded the highest mortality rate of 18.1 per 100,000 followed by the WHO Africa region (16.4) while the WHO western pacific region recorded the lowest mortality rate of 9.2. Based on continents, in 2018 Africa recorded the highest mortality rate of 17.2 per 100,000 while the lowest was recorded by Asia (11.3). The graphs below show the pictorial representation of the figures (Figure 4, Figure 5 and Figure 6).

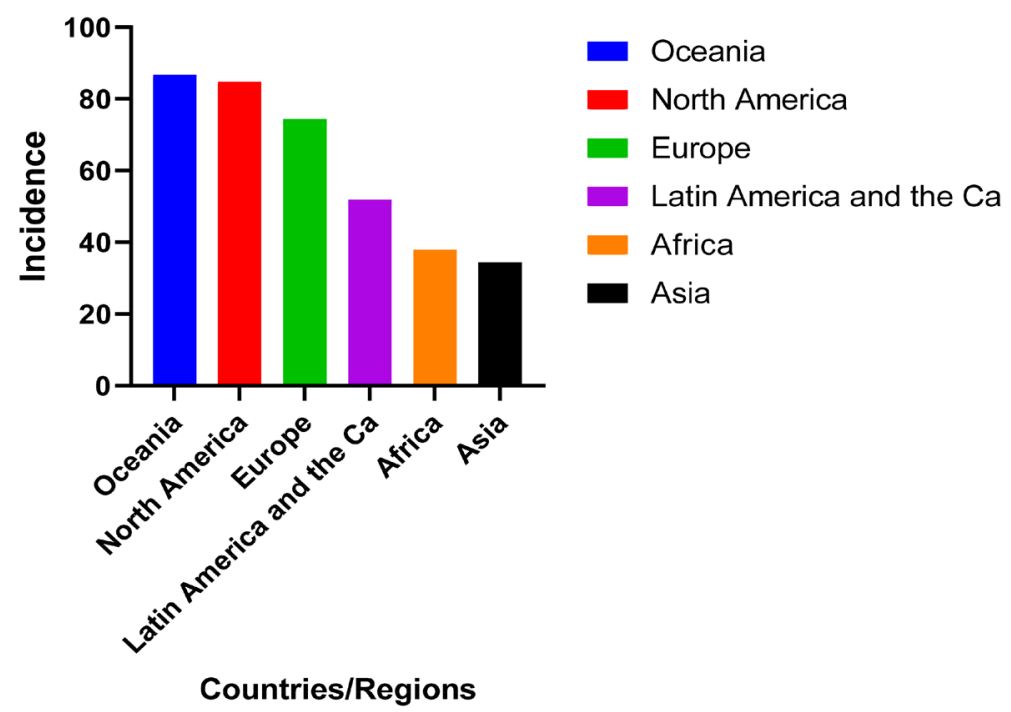

Figure 1. Distribution of breast cancer incidences among continents according to Global Cancer Observatory 2018.

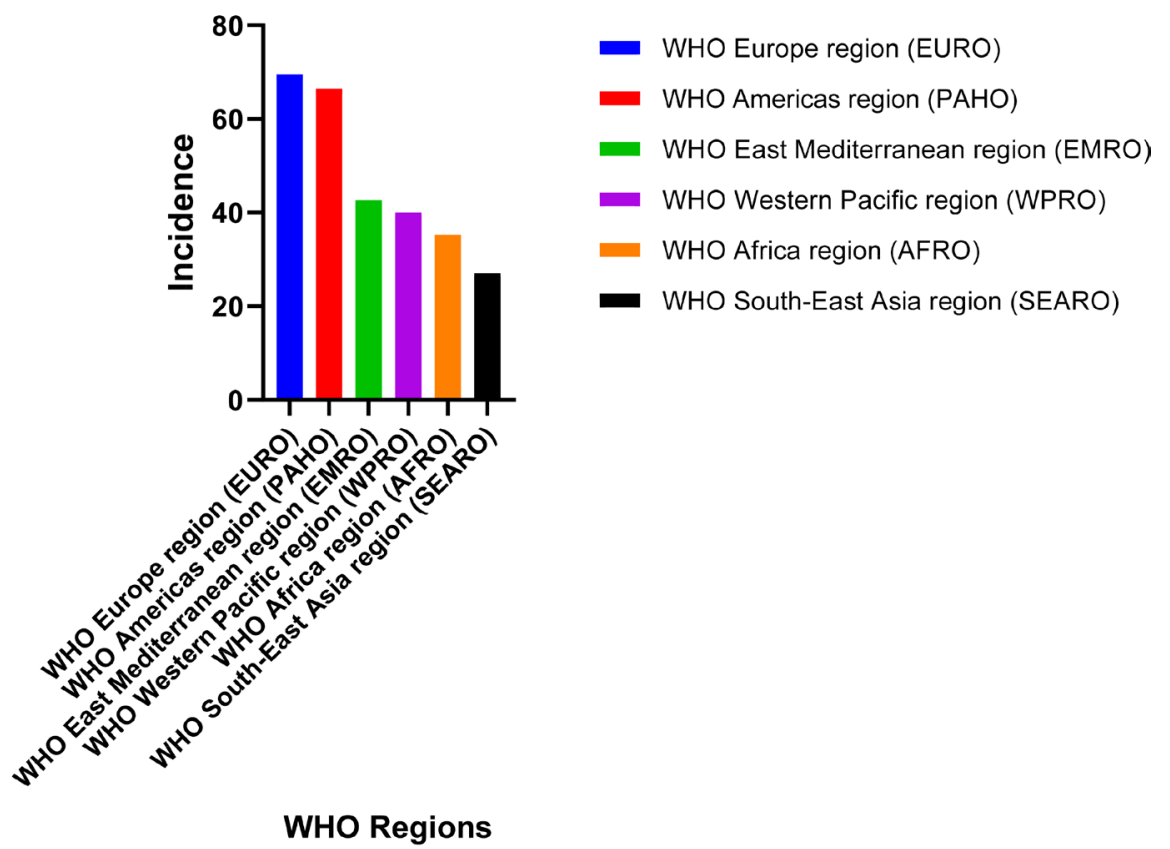

Figure 2. Distribution of breast cancer incidences among WHO regions according to Global Cancer Observatory 2018. 


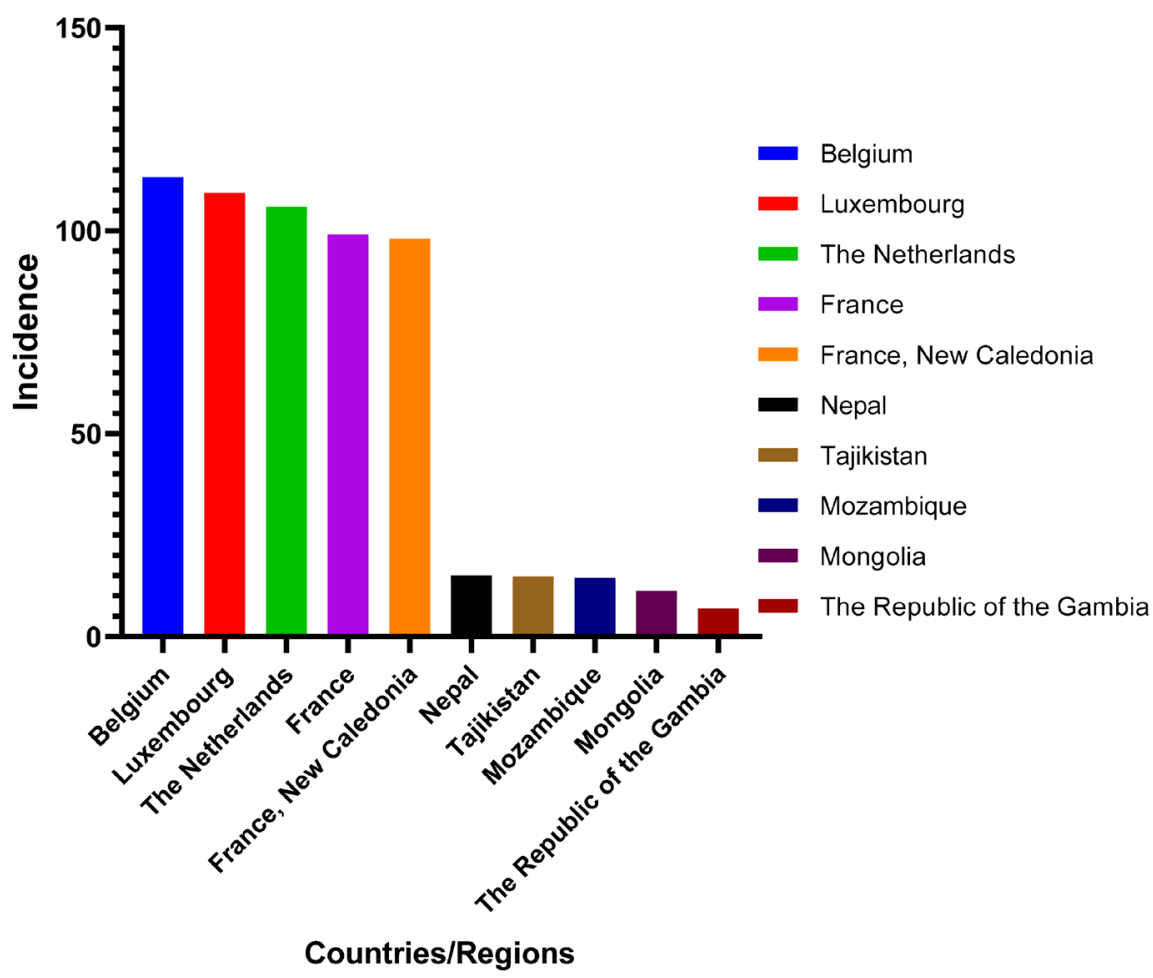

Figure 3. Distribution of breast cancer incidences among countries according to Global Cancer Observatory 2018.

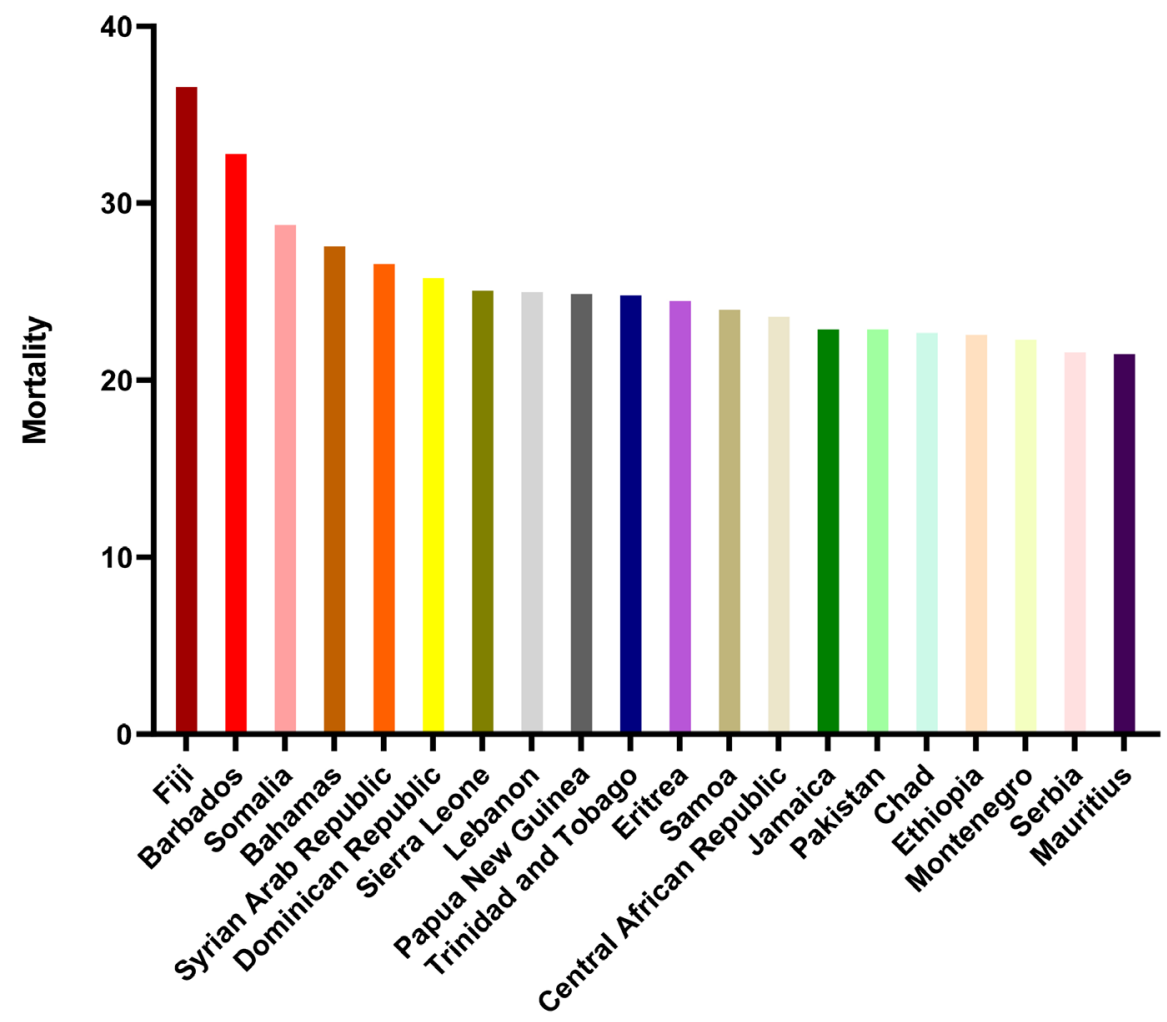

Countries/Regions

Figure 4. Distribution of mortality cases among countries according to Global Cancer Observatory 2018. 


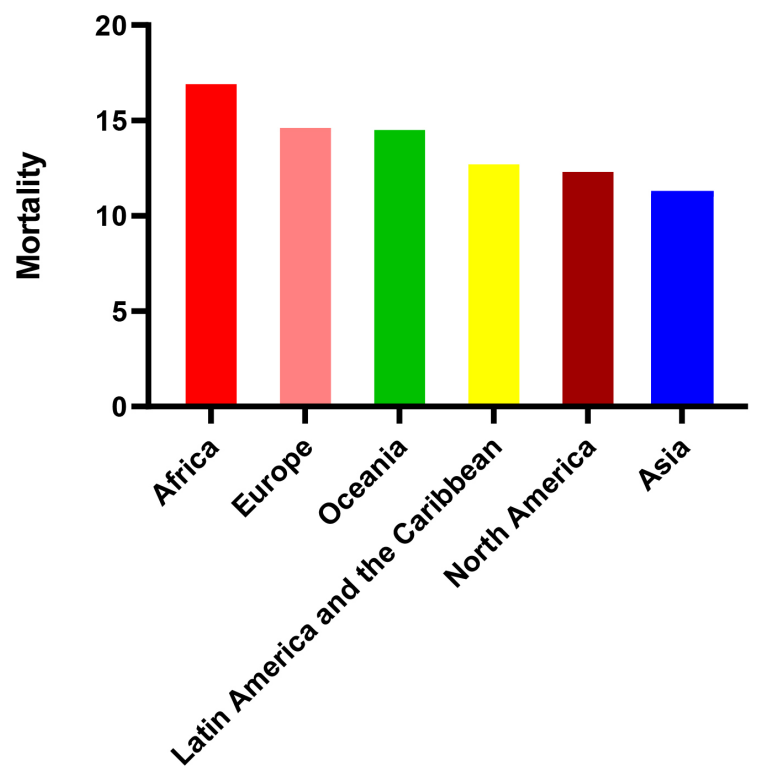

Continents

Figure 5. Distribution of mortality cases among continents according to Global Cancer Observatory 2018.

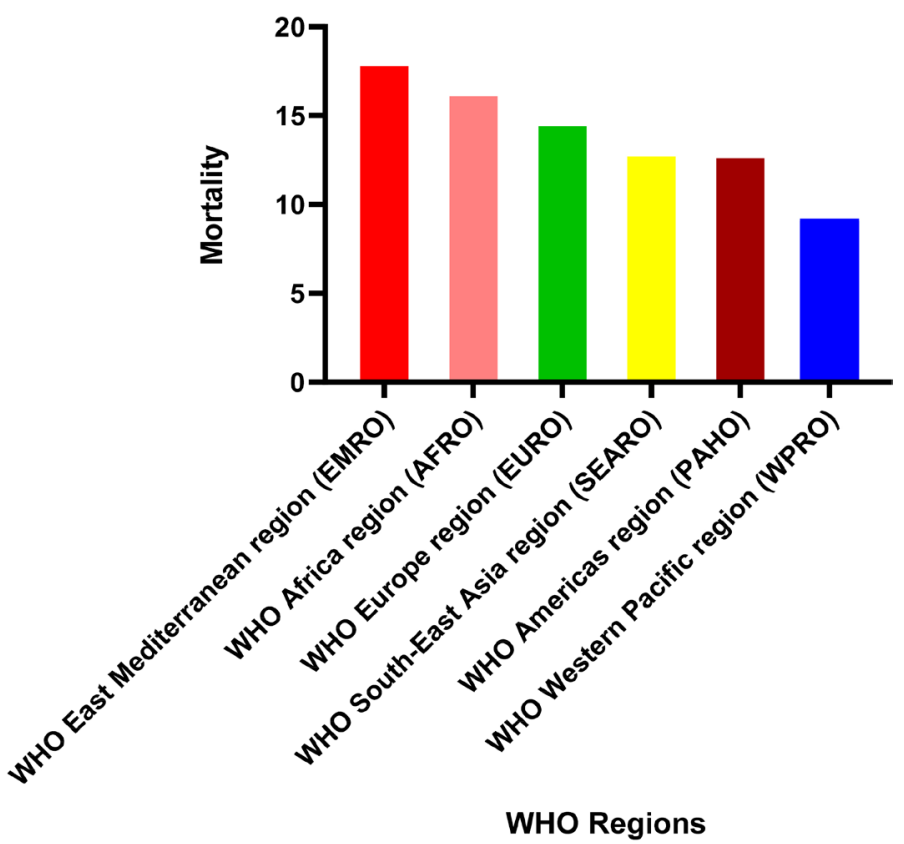

Figure 6. Distribution of mortality cases among WHO region according to Global Cancer Observatory 2018.

\subsection{Risk Factors of Breast Cancer}

The physiological abnormal changes such as hyperplasia and hypertrophy that cells in the body undergo play a role in the development of cancer [20]. These two cellular phenomena compound the issue of breast cancer by disrupting the normal growth of cells. Although medically, the science of how breast cancer occurs and the causative agents have not yet been discovered, several factors 
predispose a person especially a woman to the disease [21]. These factors are presented below:

\subsubsection{Age}

As women get older their bodies go through several hormonal imbalances, especially during menopause. Certain life processes such as pregnancy augment the shape and size of the body. Apart from that women tend to have fat deposits more as they age [22]. Though breast cancer occurs in different ages at different times, according to literature about 1 out of 8 women develop breast cancer younger than 45 years of age while about 2 out of 3 women develop breast cancer at age 55 or older. Moreover, about $80 \%$ of women aged 45 years and above are diagnosed with breast cancer each year. Also, $43 \%$ of women aged 65 years and above are diagnosed with breast cancer each year [23]. Therefore is a very substantive variable in early detection of breast cancer in women.

\subsubsection{Genetics}

Women possess the genes for breast cancer known as the BRCA1 (Breast Cancer gene one) and BRCA2 (Breast Cancer gene two) genes [24]. These genes ensure the healthy growth of cells surrounding the ovaries, breast and other cells and also repair cell damage [25]. However, mutations in these genes could lead to increased risks of breast cancer. Apart from that, these mutations could be hereditary [26]. Although researchers have established the link between breast cancer and the genes, globally only about $10 \%$ of all breast cancers are associated with the genes. Hence it does not necessarily mean that possessing the mutated gene leads to breast cancer [27]. Secondly, researchers have also discovered that single nucleotide polymorphisms (SNPs) can also be associated with increased risks in breast cancer in women possessing $B R C A 1$ gene mutation in addition to women who do not inherit the gene [28].

\subsubsection{History of Breast Cancer}

Breast cancer runs through families and women whose close relatives such as sister, mother have been diagnosed with the disease are more likely to be at risk [29]. Although, globally less than $5 \%$ of reported cases were recorded to be caused by family history [30]. As stated above mutated breast cancer genes can be inherited and hence increases risk if your close family relatives have ever been diagnosed with cancer, have been diagnosed with other cancers, women in the family have had cancers in both breasts, a male has been diagnosed with breast cancer and if relatives have been diagnosed with breast cancer before age 50 [24].

\subsubsection{Obesity}

According to global statistics for cancer recorded in 2018, 33\% of breast cancer were attributed to obesity [8]. Obesity is attributed to a lot of diseases and conditions and breast cancer is one of them. Due to unhealthy dietary choices and physical inactivity, the body changes in size and weight which can slow down metabolism and other bodily functions. Besides, fat cells known as adipocytes 
increase in number and size due to large volumes of energy getting into the body [31]. The increase in body fat increases the levels of secretion of the hormone oestrogen abnormally which increases the risk factor for breast cancer. Although the exact mechanisms by which obesity increases the risk of cancers is not yet known, the interaction of the adipose tissue with the oestrogen hormone could initiate tumour growth and progression [32].

\subsection{Diagnoses/Detection of Breast Cancer}

Several interventions have been used over the decades to improve on early detection of breast cancer to enhance survival [8] [11] [33]. The major preventive steps for breast cancer are still a distant goal hence secondary treatment through early detection seems to be the most feasible approach in contemporary society [34]. Mammography, breast self-examination and clinical breast examination have been amalgamated into different screening programs throughout the entire globe to enhance early detection where clinical breast examination (CBE) has been proven to be an important tool [35].

A clinical breast examination is usually performed physically by a professional in the health care delivery system [36]. It is normally carried out during regular medical check-up of women which could lead to the detection of various breast abnormalities including breast cancer. It is a subjective process and hence American Cancer Society does not recommend this method for breast screening. However, the United States Preventive Services Task Force also stated that there is no significant factual evidence scientifically to either approve or disapprove clinical breast examination (Siu, 2016). Notwithstanding, other breast screening methods like Mammography are designed to improve upon the traditional breast screening methods [37]. Moreover, the use of X-ray in the examination of various parts of the body has become popular in the current society. Mammography is also a form of X-ray used in the examination of the breast with a tube voltage ranging between $25 \mathrm{kVp}$ and $32 \mathrm{kVp}$ to display details of the tissue within the breast [38]. This allows for early detection and diagnosis of the disease. It detects any abnormality within the breast including the growth of cancerous cells. Mammography has been used since the 1990s and its chief purpose is to detect the disease earlier than the traditional methods of breast screening [39]. Studies have shown that regular mammography has reduced mortality of the disease over the years hence proven effective in this respect [40] [41].

Mammography has proven to be highly useful in many parts of the world especially the developed countries where there is sophisticated machinery in the health care delivery system [42]. Mammography is resource instanced and therefore highly complex; however, there is no up to date information categorically proving the effectiveness of this method in developing countries over clinical breast examination [43] [44]. This current review is systematically designed to review existing literature and highlight up to date information on the efficacy of various forms of inventions for breast cancer but specifically on mammogra- 
phy and clinical breast examination. It hopes to reveal the shortcomings of these methods and suggestions for the entire process as a form of health promotion to decrease the incidence of breast cancer in women.

\subsection{Mammography versus Clinical Breast Exam}

Breast cancer in women is a dangerous health condition that poses a threat to women's lives [11]. As is widely known, prevention is better than cure hence breast cancer in women is mostly tackled with screening as a preventive step to eradicate the disease. The process does not necessarily need evidence of breast cancer before it is carried out and therefore assessing potential people especially women for breast cancer is to detect early signs of some specific types of breast cancer likely not to even have symptoms. In detecting breast cancer methods such as mammography, clinical breast exam and self-exam are employed.

Mammography is used as a screening tool for diagnosing breast cancer. Mammography is a tool designed especially for early detections of breast cancer [45]. This is done by the detection of calcifications and characteristic masses. The process involves the use of low radiation in the form of X-ray [38]. During mammography, special measures are put in place to prevent motion blur and effects of high radiations including reducing tissue thickness that the X-rays penetrate, and therefore decreasing the number of radiations that usually scatter (scatter radiations usually decreases image quality); the radiation dose is also reduced respectively [33].

There is no vibrant study that emphatically states the importance of clinical breast exams done by a physician or health care professional. There is scanty information provided in relevant published journals that states that various tests can aid in finding breast cancer early [46]. Generally, the detection of breast cancer occurs as a result of some symptoms such as lumps by women during their day to day activities including dressing, bathing etc. [47]. It is recommended that women should know the normal nature of their breast so that they can detect changes and report to the health care professional instantaneously [48].

A study conducted by [13] revealed that out of 113 women investigated for the presentation of a tumor, about $46 \%$ where undergoing CBE, $20 \%$ on mammography. For detection of breast cancer in this study, about $93 \%$ was self-detected while $6 \%$ was also detected by mammography and finally, $1 \%$ was detected by CBE.

In comparison, although mammography is a modern method of detecting breast cancer and it is more recommended, it is very imported to utilize both methods to achieve the same results in detecting breast cancer.

\subsection{Treatment/Management of Breast Cancer}

Formerly, radical surgery was used as the sole treatment of breast cancer. Today, treatment methods have evolved due to the development of advanced technolo- 
gies and therapies [49]. Presently, methods such as chemotherapy, surgery, hormonal therapy and biological therapy are employed in the treatment of breast cancer.

Before treatment is performed, tests are conducted to determine if the tumour found is benign or maligned. The latter usually indicates that the tumour is cancerous and needs to be treated immediately. The level of tumour growth as well as the size, extent, location in the breast will determine the treatment method to be used. Hence the doctor and patient usually adopt a treatment plan suitable for the individual. The treatment is usually done a few weeks after diagnoses [50].

Breast cancer treatments are grouped into local and systemic treatments. The local treatments include radiation treatment and surgery treatment. These local treatment targets the specific area the cancerous cells are and either destroy, remove or control the cells [51]. Systemic treatments, on the other hand, target the whole body system and eradicate, destroy all cancerous cells in the body. Some examples of systemic treatments are hormone therapy and chemotherapy [52].

Surgery is one of the first forms of managing breast cancer, especially in the early stages. The stage of development of the tumour determines whether a mastectomy or modified radical mastectomy will be performed on the patient [53]. It can also be done before or after receiving some initial systemic therapy. The process involves removal of cancerous parts of the breast tissues as well as ensuring the non-cancerous part is preserved and does not affect the shape and natural look. The surgical procedure is known as lumpectomy and sometimes partial mastectomy [54]. After the surgical procedure, radiation therapy is done for six weeks to treat the remaining breast tissue. Mastectomy, another surgical procedure also involves the removal of all breast tissue followed by breast reconstruction [55].

Radiation treatment or therapy, another local treatment utilizes radiations from x-rays and other radiations to kill cancer cells and shrink tumours. However radiation therapy does not destroy cancer cells in one session but it usually takes days, weeks and sometimes months of constant radiation therapy to destroy the DNA of cancer cells for the cancer cells to die [56]. There are two types of radiation therapy known as external beam and internal. The external beam utilizes a machine that focuses on the localized cancer cells in a particular part of the body. The internal beam, on the other hand, uses capsules, seeds, ribbons that contain radiation source. These capsules, seeds, ribbons are introduced into the body and placed near the cancerous tissue to allow the therapy to take place [57].

As stated earlier, systemic treatments target the entire body and focus on all tumours that may or may not be cancerous [52]. Chemotherapy, one of the most popular cancer treatments utilizes drugs containing highly potent chemicals that destroy the rapidly-growing cancer cells in the body. There are a wide variety of chemotherapy drugs. The treatment method can be used alone or combined with other treatment methods to effectively destroy cancer cells [58]. 
Hormone therapy as its name implies is a method of treating cancer that involves treating cancer that uses/needs hormones to multiply and grow. Some breast cancers develop as a result of the use of hormones. Hence the hormone therapy prevents and stops the growth of cancer using hormones as a medium of growth. Hormone therapy is usually used in conjunction with other treatment methods such as surgery [59].

Biological therapy or immunotherapy or target therapy utilizes the body's natural system such as the immune system, hormonal system to kill and treat cancer. It targets antibodies produced in the body and uses it to destroy/block the cancer cells. This therapy also uses drugs composes of small molecules that block cancels from growing [60].

In all, all these treatment methods illustrated above are all used in combination with one another. Although some treatment methods can be used alone, according to oncologists it is better to combine the treatment methods to ensure all cancer cells have been destroyed in the breast.

\section{Analysis of Studies on Breast Cancer Screening Articles, Organizational and Reviews}

For breast cancer diagnosis, there are two different types of studies on a mammogram; these include the screening mammograms which are done on patients who present no symptoms. It comes with four X-ray pictures or images. U.S. Preventive Services Task Force endorses that, averagely, women between the ages of 50 and 74 should undergo mammography every two years [35]. This was reported in 2009 such that the recommendations triggered a lot of debate on breast cancer screening and paid attention to early screening considering mammography and clinical breast examination as appropriate tools. Other organizations such as the American Cancer Society (ACS) and the American College of Radiology (ACR) also endorsed that women should start mammography screening [7] [61] at the age of 40 [62]. Moreover in Canada and Europe, some organizations such as the Canadian Task Force on Preventive Health Care and Cancer Observatory respectively suggested that women between the ages of 50 and 69 should undergo mammography for every 2 - 3 years [63]. During screening mammography, both Craniocaudal, CC and mediolateral oblique, MLO images are taken of the breast [64]. In women between the age ranges of 39 - 69, it is reported that mammography screening decreases breast cancer mortality by about $15 \%$ [64].

ACS also endorsed CBR once every year for women at age 40 and above; they also endorsed screening with mammogram starting at age 40 and till the end of the woman's life once she is healthy [7] [61]. Reports have also indicated that almost all US medical organizations have recommended mammogram screening of women at age 40 and above. Also, it has been revealed that mammography screening reduces breast cancer in women within the ages of $50-60$ by $20-35$ percent and a bit lower in women of age $40-49$ with 14 years of checkups. The 
World Health Organization (WHO) endorsed the screening of mammography for every 1 - 2 years for women within the ages of 50 - 60 as cited in [65]. This, therefore, suggests that the efficacy of mammography in breast cancer screening in women between the ages of 50 - 69 is globally accepted. Notwithstanding, there have been sceptical debates concerning the risks and benefits of the use of mammography specifically for women in their forties. This is due to reports on false-positive results which should be balanced with advantages of screening with mammography in early ages like 40 years.

An age trial in the UK did which was first of its kind to include women at age 40 in mammography screening [66]. The trial did not propone any documented novel policies for women at age 47 for breast cancer screening by the year 2012 which was likely to result in large false-positive results. This suggests that early age screening of breast cancer with mammography is likely to result in many false-positives. Concluding on including this age group in breast cancer screening using mammography is a different issue, however, the concern of increased false-positives within the age group and leading to re-attendance has been disproved by [13]. Therefore their finding should be considered screening policymaking.

The results from a study stated that at the 40 - 49 of women, about $90 \%$ had their CBE normal. They also stated that breast imaging reporting and data system (BI-RADS) I and II had 58.4\% and $34.6 \%$ of women. They further went on to report that only about $7 \%$ of women fitted BI-RADS III and none belonged to BI-RADS IV group [13].

There are several reviews on breast cancer screen but this study considered a systematic review and met-analysis which was conducted on risk factors of getting breast cancer. The study showed that factors such as dense breast, first-degree relatives whose family have a history of breast cancer were also having at double risk for breast cancer among women of age 40 - 49 [13]. Knowing risk factors also facilitates the methods of screening tools to be used for breast cancer screening. The study also stated that knowledge of risk factors will also help to permit personalized mammography screening.

A review conducted in India among women within the ages of 39 - 40 and between the years of 2001 and 2008, which was based on an eight trial recommended strong support for mammography among young females within these ages is beneficial for them [67] [68]. India is one of the countries where breast cancer prevalence is very before age 50. Hence the results of the review paper seem to be logical in this viewpoint and making it valid.

The two review papers systematically gave us an understanding of breast cancer screening in the early ages which supported pieces of evidence from various cancer organizations around the world. Many of them are directly in line with these findings. These trends can be seen in the adapted Table 2 below.

For ages 50 - 70, this study also analyzed the results of a UK based study that revealed that breast cancer screening mammography for a three years interval 
Table 2. Recommendations for breast cancer screening for average-risk Women.

\begin{tabular}{|c|c|c|c|c|}
\hline Tool Organization & $\begin{array}{l}\text { American cancer } \\
\text { society }\end{array}$ & $\begin{array}{l}\text { American college of } \\
\text { obstetricians and } \\
\text { Gynecologists }\end{array}$ & $\begin{array}{l}\text { National Comprehensive } \\
\text { Cancer Network }\end{array}$ & $\begin{array}{c}\text { U.S. Preventive Services } \\
\text { Task Force }\end{array}$ \\
\hline $\begin{array}{l}\text { Mammography } \\
\text { start age }\end{array}$ & $\begin{array}{c}\text { Recommended between } \\
\text { age } 40-45 \text { and } \\
\text { specifically at age } 45 \\
\text { [7] [16] }\end{array}$ & $\begin{array}{c}\text { Stating at age } 40 \text { and } \\
\text { above, and } 40 \text { - } 49 \text { after } \\
\text { counselling, finally } 50 \text { years } \\
\text { if patient have not stated } \\
\text { before [69] }\end{array}$ & $\begin{array}{c}\text { Starting at } 40 \text { years and } \\
\text { above }[70]\end{array}$ & $\begin{array}{c}\text { For age } 40 \text { - } 49 \text { the starting } \\
\text { should be an individual } \\
\text { decision, however, } \\
\text { recommended age } \\
50 \text { years [17] }\end{array}$ \\
\hline $\begin{array}{l}\text { Clinical breast } \\
\text { examination }\end{array}$ & Do not recommend [7] & $\begin{array}{l}\text { For women around age } \\
25 \text { - } 39 \text { years should be } \\
1 \text { - } 3 \text { years but for women } \\
\text { at age } 40 \text { above, should } \\
\text { be done yearly [69] }\end{array}$ & $\begin{array}{l}\text { Should be every } 1-3 \text { years } \\
\text { for the ages } 25 \text { - } 39 \text { and } \\
\text { yearly for women at age } \\
40 \text { and above [12] }\end{array}$ & $\begin{array}{l}\text { May be offered for women } \\
\text { around age } 25 \text { - } 39 \text { years } \\
\text { should be } 1 \text { - } 3 \text { years but for } \\
\text { women at age } 40 \text { above, } \\
\text { should be done yearly [17] }\end{array}$ \\
\hline $\begin{array}{c}\text { Mammography } \\
\text { screening intervals }\end{array}$ & $\begin{array}{l}\text { Yearly for women at age } \\
40-45 \text {, and twice a year } \\
\text { with an option for yearly } \\
\text { screening for age } 55[7]\end{array}$ & Yearly or twice a year [69] & Annually & Biennial \\
\hline $\begin{array}{l}\text { Mammography } \\
\text { quitting age }\end{array}$ & $\begin{array}{l}\text { Done when life expectancy } \\
\text { is less than } 10 \text { years [7] }\end{array}$ & $\begin{array}{l}\text { Should be throughout once } \\
\text { initiated until age } 75 \text { and } \\
\text { stop should be based on a } \\
\text { shared-decision making [69] }\end{array}$ & $\begin{array}{l}\text { When factors limit life } \\
\text { expectancy to } 10 \text { years } \\
\text { or less }[70]\end{array}$ & $\begin{array}{l}\text { No sufficient evidence for } \\
\text { balancing problems and } \\
\text { benefits of screening at } \\
\text { above age } 75 \text { years [17] }\end{array}$ \\
\hline
\end{tabular}

within this age group extends lives. They further stated that a review of the study points out that the $20 \%$ reduction death of women was observed in the women included in the study. Their final view is that breast cancer screen prevents about 1300 deaths of women per year.

\section{Implications}

Based on the evidence provided in the literature above, it can be seen that breast cancer screening is very important for early detection, this is a sine qua non for survival.

\section{Conclusions}

Breast cancer of women is a great threat to women survival and therefore needs great attention, analysis on screening methods is therefore necessary hence this study analyzed published relevant data on the benefits of mammography over clinical breast examination with a focus on early detection. After going through several review papers, published individual articles, and organizational standards for screening, the study established that mammography is highly recommended over clinical breast examination, however, mammography is limited in that it is least practiced in remote areas. Hospitals and other health facilities have several pieces of evidence on the effectiveness of mammography in the developed world and have contributed significantly to the reduction of mortality among women with breast cancer. 
The study, therefore, recommends that governmental bodies and other organizations should help to equip areas with no mammography equipment, professional knowledge on its usage. The study also, recommends that further studies be conducted to find out the relationship between various screening methods and age groups to clarify the issue of false positives and false negatives. The study also recommends that studies being conducted on the knowledge and usage of mammographic screening in rural areas of developing centuries.

\section{Acknowledgements}

The authors acknowledge the technical support received from Priscilla Adjei-Kusi, and encouragement in carrying out this work.

\section{Availability of Supporting Data}

All data used for the study have been included in this article.

\section{Contributions}

Gadafi Iddrisu Balali perceived the idea of the manuscript, did literature search with Vera Gobe Afua Dela and wrote the manuscript, the manuscript was however refined by Denis Dekugmen Yar, Vera Gobe Afua Dela, Gadafi Iddrisu Balali, Emmanuel Effah-Yeboah, Philip Asumang, Justice Delali Akoto and Fuseini Abdallah. All authors read and approved the manuscript for final publication.

\section{Conflicts of Interest}

The authors declare no conflicts of interest regarding the publication of this paper.

\section{References}

[1] Li, J., Gao, W., Yu, L.-X., Zhu, S.-Y. and Cao, F.-L. (2017) Breast-Related Stereotype Threat Contributes to a Symptom Cluster in Women with Breast Cancer. Journal of Clinical Nursing, 26, 1395-1404. https://doi.org/10.1111/jocn.13698

[2] O’Mahony, M., Comber, H., Fitzgerald, T., Corrigan, M.A., Fitzgerald, E., Grunfeld, E.A., Flynn, M.G. and Hegarty, J. (2017) Interventions for Raising Breast Cancer Awareness in Women. Cochrane Database of Systematic Reviews, No. 2, Article ID: CD011396. https://doi.org/10.1002/14651858.CD011396.pub2

[3] Organization, W.H. (2019) Global Status Report on Alcohol and Health 2018. World Health Organization, Geneva.

[4] Smith, R.A., et al. (2016) Cancer Screening in the United States, 2016: A Review of Current American Cancer Society Guidelines and Current Issues in Cancer Screening. CA: A Cancer Journal for Clinicians, 66, 95-114. https://doi.org/10.3322/caac.21336

[5] Doss, M. (2016) Changing the Paradigm of Cancer Screening, Prevention, and Treatment. Dose-Response, 14, 1559325816680539. https://doi.org/10.1177/1559325816680539

[6] Coleman, C. (2017) Early Detection and Screening for Breast Cancer. In Seminars in Oncology Nursing. Seminars in Oncology Nursing, 33, 141-155. 
https://doi.org/10.1016/j.soncn.2017.02.009

[7] Runowicz, C.D., et al. (2016) American Cancer Society/American Society of Clinical Oncology Breast Cancer Survivorship Care Guideline. CA: A Cancer Journal for Clinicians, 66, 43-73. https://doi.org/10.3322/caac.21319

[8] Bray, F., et al. (2018) Global Cancer Statistics 2018: GLOBOCAN Estimates of Incidence and Mortality Worldwide for 36 Cancers in 185 Countries. CA: A Cancer Journal for Clinicians, 68, 394-424. https://doi.org/10.3322/caac.21492

[9] Torre, L.A., Siegel, R.L., Ward, E.M. and Jemal, A. (2016) Global Cancer Incidence and Mortality Rates and Trends-An Update. Cancer Epidemiology and Prevention Biomarkers, 25, 16-27. https://doi.org/10.1158/1055-9965.EPI-15-0578

[10] Sherman, S. and Okungu, V. (2018) Access to Breast Cancer Treatment Services in Mombasa County, Kenya: A Quality of Care Analysis of Patient and Survivor Experiences. American Journal of Public Health, 6, 189-194. https://doi.org/10.12691/ajphr-6-4-3

[11] Siu, A.L. (2016) Screening for Breast Cancer: US Preventive Services Task Force Recommendation Statement. Annals of Internal Medicine, 164, 279-296.

https://doi.org/10.7326/M15-2886

[12] Smith, R.A., et al. (2017) Cancer Screening in the United States, 2017: A Review of Current American Cancer Society Guidelines and Current Issues in Cancer Screening. CA: A Cancer Journal for Clinicians, 67, 100-121.

https://doi.org/10.3322/caac.21392

[13] Takkar, N., Kochhar, S., Garg, P., Pandey, A.K., Dalal, U.R. and Handa, U. (2017) Screening Methods (Clinical Breast Examination and Mammography) to Detect Breast Cancer in Women Aged 40-49 Years. Journal of Mid-Life Health, 8, 2-10. https://doi.org/10.4103/jmh.JMH_26_16

[14] Wellings, E., Vassiliades, L. and Abdalla, R. (2016) Breast Cancer Screening for High-Risk Patients of Different Ages and Risk-Which Modality Is Most Effective? Cureus, 8, e945. https://doi.org/10.7759/cureus.945

[15] Seely, J. and Alhassan, T. (2018) Screening for Breast Cancer in 2018-What Should We Be Doing Today? Current Oncology, 25, S115-S124. https://doi.org/10.3747/co.25.3770

[16] Saslow, D., et al. (2007) American Cancer Society Guidelines for Breast Screening with MRI as an Adjunct to Mammography. CA: A Cancer Journal for Clinicians, 57, 75-89. https://doi.org/10.3322/canjclin.57.2.75

[17] U.S. Preventive Services Task Force (2009) Screening for Breast Cancer: US Preventive Services Task Force Recommendation Statement. Annals of Internal Medicine, 151, 716. https://doi.org/10.7326/0003-4819-151-10-200911170-00008

[18] Ferlay, J., et al. (2019) Estimating the Global Cancer Incidence and Mortality in 2018: GLOBOCAN Sources and Methods. International Journal of Cancer, 144, 1941-1953. https://doi.org/10.1002/ijc.31937

[19] International Agency for Research on Cancer (2018) Global Cancer Observatory. World Health Organization. http://gco.iarc.fr

[20] Percik, R., et al. (2009) Obesity and Cancer. Experimental and Clinical Endocrinology \& Diabetes, 117, 563-566. https://doi.org/10.1055/s-0029-1241870

[21] Angahar, L.T. (2017) An Overview of Breast Cancer Epidemiology, Risk Factors, Pathophysiology, and Cancer Risks Reduction. MOJ Biology and Medicine, 1, 92-96. https://doi.org/10.15406/mojbm.2017.01.00019

[22] Kushi, L.H., et al. (2012) American Cancer Society Guidelines on Nutrition and 
Physical Activity for Cancer Prevention: Reducing the Risk of Cancer with Healthy Food Choices and Physical Activity. CA: A Cancer Journal for Clinicians, 62, 30-67. https://doi.org/10.3322/caac.20140

[23] Abdulrahman, G.O. and Rahman, G.A. (2012) Epidemiology of Breast Cancer in Europe and Africa. Journal of Cancer Epidemiology, 2012, Article ID: 915610. https://doi.org/10.1155/2012/915610

[24] Metcalfe, K., et al. (2009) Breast Cancer Risks in Women with a Family History of Breast or Ovarian Cancer Who Have Tested Negative for a BRCA1 or BRCA2 Mutation. British Journal of Cancer, 100, 421-425. https://doi.org/10.1038/sj.bjc.6604830

[25] Hilakivi-Clarke, L. (2000) Estrogens, BRCA1, and Breast Cancer. Cancer Research, 60, 4993-5001.

[26] Kapoor, N.S., et al. (2015) Multigene Panel Testing Detects Equal Rates of Pathogenic BRCA1/2 Mutations and Has a Higher Diagnostic Yield Compared to Limited BRCA1/2 Analysis Alone in Patients at Risk for Hereditary Breast Cancer. Annals of Surgical Oncology, 22, 3282-3288. https://doi.org/10.1245/s10434-015-4754-2

[27] Gage, M., Wattendorf, D. and Henry, L. (2012) Translational Advances Regarding Hereditary Breast Cancer Syndromes. Journal of Surgical Oncology, 105, 444-451. https://doi.org/10.1002/jso.21856

[28] Wong, E.M., et al. (2011) Constitutional Methylation of the BRCA1 Promoter Is Specifically Associated with BRCA1 Mutation-Associated Pathology in Early-Onset Breast Cancer. Cancer Prevention Research, 4, 23-33. https://doi.org/10.1158/1940-6207.CAPR-10-0212

[29] Berkey, C.S., et al. (2012) Young Women with Family History of Breast Cancer and Their Risk Factors for Benign Breast Disease. Cancer, 118, 2796-2803.

https://doi.org/10.1002/cncr.26519

[30] Saggu, S., et al. (2015) Recent Incidence and Descriptive Epidemiological Survey of Breast Cancer in Saudi Arabia. Saudi Medical Journal, 36, 1176-1180.

[31] Kruk, J. and Czerniak, U. (2013) Physical Activity and Its Relation to Cancer Risk: Updating the Evidence. Asian Pacific Journal of Cancer Prevention, 14, 3993-4003. https://doi.org/10.7314/APJCP.2013.14.7.3993

[32] Renehan, A.G., Zwahlen, M. and Egger, M. (2015) Adiposity and Cancer Risk: New Mechanistic Insights from Epidemiology. Nature Reviews Cancer, 15, 484-498. https://doi.org/10.1038/nrc3967

[33] Miller, K.D., et al. (2016) Cancer Treatment and Survivorship Statistics, 2016. CA: A Cancer Journal for Clinicians, 66, 271-289. https://doi.org/10.3322/caac.21349

[34] Mallory, M.A. and Golshan, M. (2018) Examination Techniques: Roles of the Physician and Patient in Evaluating Breast Disease. In: Bland, K.I., et al., Eds., The Breast, Elsevier, Amsterdam, 331-336. E2. https://doi.org/10.1016/B978-0-323-35955-9.00025-8

[35] Bibbins-Domingo, K., Grossman, D.C. and Curry, S.J. (2017) The US Preventive Services Task Force 2017 Draft Recommendation Statement on Screening for Prostate Cancer: an Invitation to Review and Comment. JAMA, 317, 1949-1950. https://doi.org/10.1001/jama.2017.4413

[36] Desantis, C.E., et al. (2016) Breast Cancer Statistics, 2015: Convergence of Incidence Rates between Black and White Women. CA: A Cancer Journal for Clinicians, 66, 31-42. https://doi.org/10.3322/caac. 21320

[37] Verma, B. and Zakos, J. (2001) A Computer-Aided Diagnosis System for Digital 
Mammograms Based on Fuzzy-Neural and Feature Extraction Techniques. IEEE Transactions on Information Technology in Biomedicine, 5, 46-54. https://doi.org/10.1109/4233.908389

[38] Highnam, R. and Brady, J.M. (2012) Mammographic Image Analysis. Springer Science \& Business Media, Berlin.

[39] Sosu, E.K. (2018) Optimization of Radiological Protection of Patients Undergoing Mammography Examination in Ghana. University of Cape Coast, Cape Coast.

[40] Byers, T., et al. (2016) the American Cancer Society Challenge Goal to Reduce US Cancer Mortality by 50\% between 1990 and 2015: Results and Reflections. CA: $A$ Cancer Journal for Clinicians, 66, 359-369. https://doi.org/10.3322/caac.21348

[41] Løberg, M., Lousdal, M.L., Bretthauer, M. and Kalager, M. (2015) Benefits and Harms of Mammography Screening. Breast Cancer Research, 17, Article No. 63. https://doi.org/10.1186/s13058-015-0525-Z

[42] Pitcher, R.D. (2019) The Role of Radiology in Global Health, in Radiology in Global Health. Springer, Berlin, 157-174. https://doi.org/10.1007/978-3-319-98485-8_14

[43] Coles, C., et al. (2017) Partial Breast Radiotherapy After Breast Conservation Surgery for Early Breast Cancer: 5-Year Outcomes from the IMPORT LOW (CRUK/06/003) Phase III Randomised Controlled Trial.

[44] Da Costa Vieira, R.A., et al. (2017) Breast Cancer Screening in Developing Countries. Clinics, 72, 244-253. https://doi.org/10.6061/clinics/2017(04)09

[45] Omidiji, O.A., et al. (2017) Breast Cancer Screening in a Resource Poor Country: Ultrasound versus Mammography. Ghana Medical Journal, 51, 6-12. https://doi.org/10.4314/gmj.v51i1.2

[46] Torre, L.A., et al. (2015) Global Cancer Statistics, 2012. CA: A Cancer Journal for Clinicians, 65, 87-108. https://doi.org/10.3322/caac.21262

[47] Bonsu, A.B. and Ncama, B.P. (2019) Recognizing and Appraising Symptoms of Breast Cancer as a Reason for Delayed Presentation in Ghanaian Women: A Qualitative Study. PLoS ONE, 14, e0208773. https://doi.org/10.1371/journal.pone.0208773

[48] Smith, P., et al. (2018) Feasibility and Acceptability of a Cancer Symptom Awareness Intervention for Adults Living in Socioeconomically Deprived Communities. BMC Public Health, 18, Article No. 695. https://doi.org/10.1186/s12889-018-5606-3

[49] Dragun, A.E., et al. (2013) Increasing Use of Elective Mastectomy and Contralateral Prophylactic Surgery among Breast Conservation Candidates: A 14-Year Report from a Comprehensive Cancer Center. American Journal of Clinical Oncology, 36, 375-380.

[50] Elmore, J.G., et al. (2005) Screening for Breast Cancer. JAMA, 293, 1245-1256. https://doi.org/10.1001/jama.293.10.1245

[51] Girish, C., et al. (2014) A Review on Breast Cancer. International Journal of Pharma and Bio Sciences, 4, 47-54.

[52] Bae, Y.H. andPark, K. (2011) Targeted Drug Delivery to Tumors: Myths, Reality and Possibility. Journal of Controlled Release, 153, 198-205. https://doi.org/10.1016/j.jconrel.2011.06.001

[53] Sharma, G.N., et al. (2010) Various Types and Management of Breast Cancer: an Overview. Journal of Advanced Pharmaceutical Technology \& Research, 1, 109-126.

[54] Jung, B.F., et al. (2003) Neuropathic Pain Following Breast Cancer Surgery: Proposed Classification and Research Update. Pain, 104, 1-13. https://doi.org/10.1016/S0304-3959(03)00241-0 
[55] Khan, F.M. and Gibbons, J.P. (2014) Khan's the Physics of Radiation Therapy. Lippincott Williams \& Wilkins, Philadelphia.

[56] Baskar, R., et al. (2012) Cancer and Radiation Therapy: Current Advances and Future Directions. International Journal of Medical Sciences, 9, 193-199. https://doi.org/10.7150/ijms.3635

[57] Whelan, T.J., et al. (2010) Long-Term Results of Hypofractionated Radiation Therapy for Breast Cancer. New England Journal of Medicine, 362, 513-520. https://doi.org/10.1056/NEJMoa0906260

[58] Cheung-Ong, K., Giaever, G. and Nislow, C. (2013) DNA-Damaging Agents in Cancer Chemotherapy: Serendipity and Chemical Biology. Chemistry \& Biology, 20, 648-659. https://doi.org/10.1016/j.chembiol.2013.04.007

[59] Beral, V., et al. (2011) Breast Cancer Risk in Relation to the Interval between Menopause and Starting Hormone Therapy. Journal of the National Cancer Institute, 103, 296-305. https://doi.org/10.1093/jnci/djq527

[60] Kwak, J.J., et al. (2015) Cancer Immunotherapy: Imaging Assessment of Novel Treatment Response Patterns and Immune-Related Adverse Events. Radiographics, 35, 424-437. https://doi.org/10.1148/rg.352140121

[61] Ray, K.M., et al. (2018) Screening Mammography in Women 40-49 Years Old: Current Evidence. American Journal of Roentgenology, 210, 264-270. https://doi.org/10.2214/AJR.17.18707

[62] Feig, S.A. (2016) Assessment of New American Cancer Society Guidelines for Screening Mammography. Breast Diseases. A Year Book Quarterly, 27, 251-254. https://doi.org/10.1016/j.breastdis.2016.10.025

[63] Dombrovskiy, V. and Khachatryan, G. (2017) Comparison of Recommended Screening Programs in the United States, Canada, the Netherlands and Germany. PHARMACOECONOMICS. Modern Pharmacoeconomics and Pharmacoepidemiology, 9, 46-53. https://doi.org/10.17749/2070-4909.2016.9.4.046-053

[64] Mitra, P. (2016) Computer Based Analysis of Mammogram Images to Treat Breast Cancer. Wichita State University, Wichita.

[65] Smith, R.A., Cokkinides, V. and Brawley, O.W. (2012) Cancer Screening in the United States, 2012: A Review of Current American Cancer Society Guidelines and Current Issues in Cancer Screening. CA: A Cancer Journal for Clinicians, 62, 129-142. https://doi.org/10.3322/caac.20143

[66] Moss, S.M., et al. (2006) Effect of Mammographic Screening from Age 40 Years on Breast Cancer Mortality at 10 Years' Follow-Up: A Randomised Controlled Trial. The Lancet, 368, 2053-2060. https://doi.org/10.1016/S0140-6736(06)69834-6

[67] Narod, S.A. (2012) Breast Cancer in Young Women. Nature Reviews Clinical Oncology, 9, 460-470. https://doi.org/10.1038/nrclinonc.2012.102

[68] Rivers, D., et al. (2013) A Systematic Review of the Factors Influencing African Americans' Participation in Cancer Clinical Trials. Contemporary Clinical Trials, 35, 13-32. https://doi.org/10.1016/j.cct.2013.03.007

[69] Centers for Disease Control and Prevention (CDC) (2007) Use of Mammograms among Women Aged $>$ or $=40$ Years-United States, 2000-2005. MMWR. Morbidity and Mortality Weekly Report, 56, 49.

[70] Helvie, M.A. and Bevers, T.B. (2018) Screening Mammography for Average-Risk Women: the Controversy and NCCN's Position. Journal of the National Comprehensive Cancer Network, 16, 1398-1404. https://doi.org/10.6004/jnccn.2018.7081 